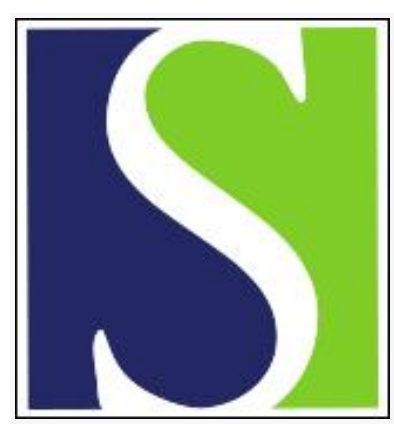

Scand J Work Environ Health 2012;38(6):503-515

https://doi.org/10.5271/sjweh.3274

Published online: 18 Jan 2012, Issue date: 01 Nov 2012

Unrecognized risks of nickel-related respiratory cancer among Canadian electrolysis workers

by Grimsrud TK, Andersen A

Affiliation: Department of Research, Cancer Registry of Norway, PB 5313 Majorstuen, NO-0304 Oslo, Norway. tom.k.grimsrud@kreftregisteret.no

Refers to the following texts of the Journal: 2000;26(4):338-345 1990;16(1):1-82

Key terms: Canada; carcinogen; copper; electrolysis; electrolysis worker; epidemiology; exposure; lung cancer; lung cancer; mortality; nasal cancer; nickel; Norway; refinery; respiratory cancer; review; sinonasal cancer

This article in PubMed: www.ncbi.nlm.nih.gov/pubmed/22258056 


\title{
Unrecognized risks of nickel-related respiratory cancer among Canadian electrolysis workers
}

\author{
by Tom K Grimsrud, MD, ${ }^{1}$ Aage Andersen ${ }^{2}$
}

Grimsrud TK, Andersen A. Unrecognized risks of nickel-related respiratory cancer among Canadian electrolysis workers. Scand J Work Environ Health. 2012;38(6):503-515. doi:10.5271/sjweh.3274

Objectives Nickel compounds, inclusive of water-soluble salts, have been classified as human carcinogens by
the International Agency for Research on Cancer (IARC). Nickel producers have disputed the classification of
soluble nickel compounds for three decades with reference to an alleged absence of excess respiratory cancer
among Canadian nickel-exposed electrolysis workers. We evaluated historical data from two electrolytic refiner-
ies in Ontario, both included in prominent Canadian reports on occupational nickel-related cancer.

Methods For Port Colborne nickel refinery (PCNR) and Copper Cliff copper refinery (CCCR), we identified process descriptions, exposure estimates, and original reports on cancer mortality using reference lists, libraries, and state archives. The documents were written or published between 1930 and 1992.

Results For PCNR, a 1977 US National Institute of Occupational Safety and Health criteria document demonstrated an excess nasal cancer risk among electrolysis workers independent of furnace exposure. PCNR studies published after 1980 excluded $26 \%$ of long-term refiners who died from respiratory cancer according to earlier reports, and $42 \%$ of the workers had unknown vital status at the end of follow-up, biasing the standardized observed-to-expected mortality ratios downwards, most pronounced in recent reports and for workers without pension or company benefits. CCCR reports did not adequately address soluble nickel exposure in the evaluation of an observed occupational lung cancer excess.

Conclusions While acknowledging important contributions to the recognition of nickel carcinogenicity from highly exposed Canadian refiners, we conclude that the claimed absence of nickel-related respiratory cancer among electrolysis workers has resulted from an arbitrary overemphasis of biased and inconclusive findings.

Key terms Canada; carcinogen; copper; epidemiology; exposure; lung cancer; mortality; nasal cancer; Norway; refinery; review; sinonasal cancer.

Nickel is widely distributed in nature and is a common component in industrial products and consumer merchandise (1). The refining of nickel ore has been linked to cancer excess at a Welsh refinery (UK) for 80 years (2). Case reports on nasal (sinonasal) cancer and lung cancer emerged during the 1930s and 1940s (3-5), and a company investigation was conducted by Austin Bradford Hill in 1939 [referred to in (6)]. By 1958, the first epidemiological paper appeared in a medical journal (7), and, one year later, a report to Canadian health authorities was the first to demonstrate similar risks among furnace workers at a refinery outside the UK (8). Based on a new study and a mortality update from the British and Canadian refineries $(9,10)$, and some case reports from other countries, a working group at the Interna- tional Agency for Research on Cancer (IARC) ascribed the effect to nickel "in some form" in 1972 (11).

Somewhat surprisingly, a subsequent study from a refinery in Kristiansand, Norway, (12) showed high risks of respiratory cancer among electrolysis workers, suggesting a carcinogenic effect from water-soluble nickel compounds, which is the main exposure in such departments. Increased risks of respiratory cancer had now been found in three groups of nickel workers: (i) those engaged in furnace departments (roasting, sintering, smelting, and calcining) $(6,7,12)$; (ii) those producing water-soluble nickel and copper salts (sulphates) from aqueous solutions (6); and (iii) those involved in the electrolytic extraction of pure nickel or copper from electrolytes with a high level of nickel sulphate or nickel chloride (12).

1 Department of Research, Cancer Registry of Norway, Oslo, Norway.

2 Head of Department of Research (retired), Cancer Registry of Norway, Oslo, Norway.

Correspondence to: Tom K Grimsrud, MD PhD, Researcher, Department of Research, Cancer Registry of Norway, PB 5313 Majorstuen, NO-0304 Oslo, Norway. [Email: tom.k.grimsrud@kreftregisteret.no] 
The discussion of which forms of nickel lead to respiratory cancer was addressed in a comprehensive epidemiological study by the International Committee on Nickel Carcinogenesis in Man (ICNCM), headed by Sir Richard Doll. In 1990, the Committee concluded that more than one form of nickel increased the risk (13), with the strongest evidence found for soluble nickel compounds (water-soluble salts) and particles containing nickel oxides and nickel sulphides. Accordingly, the IARC classified nickel compounds as human carcinogens in 1990 (1). The decision was re-confirmed by a new IARC working group in 2009 (14).

The carcinogenicity of the subgroup of water-soluble nickel compounds has been disputed by parts of the nickel-producing industry or their paid consultants for more than 30 years, as seen in historical documents such as those sent to the US National Institute of Occupational Safety and Health (NIOSH) in 1976 (15) and the US Occupational Safety \& Health Administration (OSHA) in 1988 (16). The argument continued after 1990 in articles, information, and reviews sponsored by nickel producers (17-19), despite additional epidemiological evidence of carcinogenicity from the UK, Finland, and Norway (20-25).

The clearest evidence has been found among electrolysis workers, who are exposed to relatively low levels of total nickel, most of it existing as water-soluble salts, although often combined with small amounts of insoluble compounds $(13,22,26,27)$. These exposures contrast those of furnace work, as the latter have been characterized by high levels of total nickel, predominantly nickel oxides and nickel sulphides, and relatively small proportions of soluble salts. The high risks observed in different groups of refiners therefore indicate a central role of soluble nickel in the carcinogenic process.

It has been claimed that Canadian electrolysis workers - most specifically at the Port Colborne nickel refinery (PCNR) in Ontario - constitute an exception by not having experienced the same cancer risks as those observed among their European colleagues $(8,9,13,28,29)$. The apparent diverging results across cohorts with assumed similar exposures, especially the comparison of the Norwegian and Canadian experiences, have been the basis of a reoccuring argument over whether soluble nickel should be regarded as carcinogenic, even throughout the last decade $(19,30,31)$. The ICNCM discussed the difference in risk in 1990 but was not able to fully explain the observation (13).

We have seen no attempt by Canadian researchers to contribute to the debate with updated cancer mortality or improved exposure estimates from the PCNR cohort. We therefore chose to review critically the available historical data on working conditions and cancer mortality at the two most relevant Canadian electrolytic facilities: PCNR and the Copper Cliff copper refinery (CCCR). Cancer mortality was first reported from these two refineries in 1959 and 1971, respectively $(8,32)$, and both refineries were included in the prominent Canadian cohort of Ontario nickel workers, which contributed more than two thirds of the workers included in the large ICNCM study (13). The electrolytic processes were operated in the periods 1926-1984 (PCNR) and 1930-2005 (CCCR).

For a better understanding of potential exposures to water-soluble nickel at the refineries, we also present some basic process data for the plants, and, for comparison, corresponding data for the electrolytic processes at the nickel and copper refinery in Kristiansand, Norway.

\section{Methods}

Information on plant-specific technical and chemical issues relevant to occupational exposures was sought in chemistry literature and engineering journals. Epidemiological studies on cancer mortality were searched for in reference lists, publicly available internet-based archives, and state agencies with regulatory, environmental, and safety and health responsibilities. Exposure data were found in reports, journals, and epidemiological studies.

Some cancer reports existed in multiple versions, and, if possible, we gave priority to articles published in peer-reviewed journals. Unpublished epidemiological reports from the period 1959-1977 were delivered from health and environmental authorities in Canada and the US. Cancer risks were reported as standardized mortality ratios (SMR) based on comparison of observed and expected numbers of cancer deaths, the latter derived from age-, calendar year-, and gender-specific mortality rates for the population of Ontario.

We focused mainly on nasal cancer epidemiology, as the risk of this rare disease has been highly increased among nickel-exposed workers and because no strong confounder seems to exist in the refineries. Lung cancer mortality, on the other hand, is highly influenced by shifts in tobacco smoking, and the occupational risks are therefore more difficult to evaluate in historical data.

Within this Methods section, we refer to some relevant exposure and process data, with special attention directed towards electrolysis work and soluble nickel exposure. In the Results section, we present the main findings of the cancer mortality reports; and, finally, we discuss some epidemiological and interpretational implications.

\section{Exposures}

Data on historical nickel exposures in refineries are known to be scarce and insufficient for a formal comparison (13). For the PCNR electrolysis department, some exposure data were submitted by the owner company in 
1976 to NIOSH [(15) p79], based on a low number of stationary and personal measurements. In a review in 1984, Warner presented exposure estimates for nickel refineries but no plant-specific data were provided (33).

The ICNCM was the first to develop nickel exposure estimates for the Welsh and Norwegian refineries, but the corresponding data for Canadian electrolysis workers were less complete and largely recorded as ranges with an upper limit only. The ICNCM discussed nickel exposures at the PCNR and Norwegian nickel electrolysis departments [(13) pp20,50-51, 55-56,70-71] and found indications that the levels of water-soluble nickel were somewhat lower at the Canadian plant. A more recent assessment suggested that the ICNCM estimates for the Norwegian plant may have been too high (26). Nickel exposures in the CCCR and the Norwegian copper refinery were never explicitly discussed or compared.

For the CCCR, an industrial hygiene investigation focused on exposure to polycyclic aromatic hydrocarbons (PAH) arising from asphalt and tar covering of the tank-house floor (34). No data on nickel were provided except for a statement that nickel exposures were "relatively low" for lead welders.

Although workers' exposures cannot be derived directly from process descriptions, such data are less vulnerable to variation in sampling technique, location of samplers, and laboratory analyses, which are common problems in historical exposure measurements. Chemical and technical data may be of great value for the understanding of the work conditions, and in order to support our discussion and interpretation, we provide a brief description of the Canadian plants, along with corresponding data for the Norwegian refinery for comparison.

\section{Port Colborne nickel refinery process}

The PCNR was commissioned in 1918 as the first Canadian works to produce furnace-refined nickel oxide and ingots $(35,36)$. Electrolytic refining started in 1926, with the production of virtually pure nickel metal. Raw materials, in the form of sulphidic and oxidic nickel concentrates, were treated with leaching, sintering, and casting of metallic nickel anodes before the final electrolysis. Some very dusty furnace processes were terminated in 1958 (sintering) and 1973 (calcining) (28). Electrolytic refining of nickel ceased at PCNR in 1984.

By far, most of the pure nickel was produced by the so-called "Hybinette electrolysis", where nickel ions were supplied to the electrolyte by corrosion of impure metallic anodes submersed in electrolytic tanks. The resulting impure electrolyte had to be continuously drained and treated to remove metals other than nickel. Purified electrolyte was subsequently redirected to the tanks, directly into filter compartments made of wooden frames with canvas bags. There were 30 compartments in each tank, each of them enclosing a cathode. Pure nickel $(>99.5 \%$ $\mathrm{Ni}$ ) was deposited on these cathodes, while spent pure electrolyte continuously seeped out through the canvas to blend with the impure electrolyte (37-39).

Typical contents of nickel in the impure anodes and the electrolyte are presented in table 1 (column 2), with corresponding values for the similar process at the Kristiansand nickel refinery, Norway (column 3). The nickel anodes at the Norwegian plant contained substantially more impurities (mainly copper and iron), requiring a more comprehensive purification procedure, with its rather sloppy precipitation and filtering steps. Additionally, the amount of nickel salts dissolved in the electrolyte was greater at the Norwegian plant.

\section{Copper Cliff copper refinery process}

In 1930, the CCCR was established for electrolytic processing of concentrates originating from the same ore as those treated by PCNR. Copper and nickel tend to follow each other in the intermediates, and substantial exposure to nickel may take place in a copper electrolysis. At CCCR, copper ions were supplied to the electrolyte by corrosion of impure metallic anodes holding $99.2 \%$ copper and a modest $0.5 \%$ nickel (table 1 , column 4 ) (40). The latter percentage was characterized in 1942 as "larger amounts of nickel than that found at most [copper, authors' comment] refineries" [(41) p293].

Differences in electrochemical properties allow copper ions to be deposited on cathodes while nickel ions remain in the solution. A total removal of nickel ions is therefore not necessary, but the preferential deposition leads to a continuous accumulation of nickel in the electrolyte. Special measures were therefore taken at CCCR to keep nickel down to a chosen level of $20 \mathrm{~g} /$ nickel per liter during steady-state (42). Further data are given in table 1, together with corresponding values for the copper electrolysis that is part of the nickel refinery at Kristiansand, Norway (column 5).

Data on soluble nickel in the CCCR copper electrolyte were hard to find, and - notably - provided neither in any of the relevant epidemiological reports from 1971-1992 (13, 29, 32, 43) nor in the 1992 industrial hygiene report from the refinery (34) or reviews of nickel-related cancer conducted since the 1970s $(1,13$, $19,30,44-46)$. We found relevant data in books on chemistry and metallurgy printed between 1930 and 1960 (40-42). Curbing of the nickel in the electrolyte was necessary in the Canadian as well as the Norwegian copper tank-house for process efficiency reasons, and it was obtained by a continuous "bleeding" (draining) of electrolyte, rich in nickel, for subsequent treatment with copper depletion and production of purified nickel sulphate by precipitation, filtering, washing, crystallization, and drying steps $(37,42)$. 
Table 1. Characteristics of the electrolytic processes at Port Colborne and Copper Cliff refineries, both Ontario, Canada, and at the Kristiansand refinery, Norway.

\begin{tabular}{|c|c|c|c|c|}
\hline Characteristic & $\begin{array}{l}\text { Port Colborne Hybinette } \\
\text { nickel electrolysis }{ }^{a}\end{array}$ & $\begin{array}{l}\text { Kristiansand Hybinette } \\
\text { nickel electrolysis a b }\end{array}$ & $\begin{array}{l}\text { Copper Cliff copper } \\
\text { electrolysis }^{c}\end{array}$ & $\begin{array}{l}\text { Kristiansand copper } \\
\text { electrolysis }{ }^{b}\end{array}$ \\
\hline First year of operation & 1926 & 1910 & 1930 & 1910 \\
\hline Last year of operation & 1984 & In operation ${ }^{d}$ & 2005 & In operation \\
\hline Nickel in impure anodes & $95 \%$ & $70-77 \%$ & $0.5 \%$ & e \\
\hline Copper in impure anodes & $2-3 \%$ & $18-25 \%$ & $99.2 \%$ & . \\
\hline Iron in impure anodes & $<1 \%$ & $0.3-1.6 \%$ & $0.0 \%$ & . \\
\hline Sulphur in impure anodes & $<1 \%$ & $1.1-4.5 \%$ & . & . \\
\hline Anodes per tank & 31 & 38 & 38 & 33 \\
\hline Cathodes per tank & 30 & 37 & 39 & 32 \\
\hline Nickel in electrolyte & $40-60 \mathrm{~g} / \mathrm{L}$ & $60-70 \mathrm{~g} / \mathrm{L}$ & $20 \mathrm{~g} / \mathrm{L}$ & $40-70 \mathrm{~g} / \mathrm{L}$ \\
\hline Copper in electrolyte & .. & $0-2.3 \mathrm{~g} / \mathrm{L}$ & $39 \mathrm{~g} / \mathrm{L}$ & $70-75 \mathrm{~g} / \mathrm{L}$ \\
\hline Generation of gas bubbles at the anodes & . & d & Few tanks only & Most tanks \\
\hline Temperature of solution & $55^{\circ} \mathrm{C}$ & $60^{\circ} \mathrm{C}$ & $60-65^{\circ} \mathrm{C}$ & .. \\
\hline
\end{tabular}

a Chemical data from Walter, 1931 [(39), p189]; Inco staff, 1946 [(35), p195]; Gmelin, 1967 [(38), p551-3].

b Chemical data from unpublished documents prepared for the International Committee on Nickel Carcinogenesis in Man (ICNCM) by Chief Metallurgist PG Thornhill, 1986.

c Chemical data from Gmelin, 1955 [(40), p574-5].

a New refining process introduced 1978, a shift from Hybinette to chlorine leach process with insoluble anodes.

e The Kristiansand copper electrolysis uses insoluble lead anodes, while copper ions are supplied to the tanks in an aqueous solution (electro-winning).

The CCCR ran an electro-refining process, meaning that impure metallic copper anodes were consumed, while refined copper cathodes were produced within the same tanks. By contrast, the electro-winning tanks at Kristiansand received copper as sulphates in aqueous solution for direct deposition on the cathodes. The discrepancy is essential for the working environment: the Kristiansand electro-winning copper electrolysis - in line with the Finnish electro-winning nickel electrolysis at Harjavalta [(27); (38) pp527, 545], noted for its excess of respiratory cancer (22) - experienced (and still experiences) a continuous generation of bubbles from the surface of the submerged insoluble lead anodes at a rate proportional to the production [(40) p578]. Nickelcontaining aerosols are produced when the numerous bubbles burst at the surface of the electrolyte.

At CCCR, generation of bubbles was a minor problem, largely restricted to a few "liberating tanks" and the adjacent "acid recovery plant" where nickel sulphate was produced $(41,42)$. Nickel-containing aerosols in the main copper tank-house at CCCR would thus, in general, be expected to be low, and reach its maximum around and above tanks where large racks of electrodes were handled (submersed or hoisted) - as was done regularly every two weeks for each of the 1200 tanks by steady-state production - or in situations with repairs, spills, and cleaning (42).

\section{Results}

We found ten reports with epidemiological data covering employments between 1914 and 1976, presenting follow-up for cancer mortality in the time span 1930-
1984. Data from the nine most relevant ones are shown in tables 2 and 3 . We found no cancer mortality data to cover follow-up after 1984 for any of the two refineries.

\section{Port Colborne early studies}

The cancer reports from the PCNR can conveniently be divided into early studies (1959-1977) and studies after 1980 (1984-1992). The 1959 report was a milestone (8), clearly demonstrating a cancer excess similar to the one thought to be unique for the refinery workers in Clydach, South Wales. The first PCNR study included 2355 long-term refinery workers, employed for $\geq 5$ years between 1925 and 1957, with a follow-up for death from 1930 through 1957 or 1959 (table 2) (8). The overall lung cancer mortality rate among 292 highly exposed furnace workers was 3-4 times the expected one (not shown separately in our table), while the nasal cancer SMR was an order of magnitude higher.

The first PCNR study also included 225 workers with electrolysis experience only, among whom a single lung cancer death ( 0.9 expected) and no nasal cancers $(0.02$ expected) were reported (8). The individual occupational histories were, however, revised during the final writing of the report, and table 4 shows the original distribution and subsequent re-distributions, according to exposure group, of all men reported to have nasal cancer through 1976. By 1967, there was still no recognized risk among electrolysis workers (9), although 11 out of 16 nasal cancer deaths (table 4) and 22 out of 37 lung cancer deaths (the latter not shown in table) occurred among workers with "mixed exposures" (ie, exposure from more than one department). No attempt was made to assess the effect from co-exposure in non-furnace departments. 
Table 2. Table 2. Respiratory cancer mortality and some additional incident cases 1930-1984 among Port Colborne nickel-refinery workers, Canada. [add=additional; exp=expected; ICNCM=International Committee on Nickel Carcinogenesis in Man; LCS=Leaching, calcining, and sintering departments; NIOSH=US National Institute of Occupational Safety and Health; obs=observed]

\begin{tabular}{|c|c|c|c|c|c|c|c|c|c|c|c|}
\hline \multirow{3}{*}{$\begin{array}{l}\text { Data source } \\
\text { article/report } \\
\text { [table=tbl] }\end{array}$} & \multirow{3}{*}{$\begin{array}{l}\text { Study } \\
\text { size }\end{array}$} & \multirow{2}{*}{\multicolumn{2}{|c|}{$\begin{array}{l}\text { Criteria for } \\
\text { inclusion }\end{array}$}} & \multirow{3}{*}{$\begin{array}{l}\text { Follow-up } \\
\text { period } \\
\text { (years) }\end{array}$} & \multirow{3}{*}{$\begin{array}{l}\text { Outcome } \\
\text { source }\end{array}$} & \multicolumn{6}{|c|}{ Cancer outcome } \\
\hline & & & & & & \multicolumn{3}{|c|}{ Lung cancer } & \multicolumn{3}{|c|}{ Nasal cancer } \\
\hline & & $\begin{array}{l}\text { Minimum } \\
\text { employment }\end{array}$ & $\begin{array}{l}\text { Other } \\
\text { requirements }\end{array}$ & & & $\begin{array}{l}\text { Deaths } \\
\text { (obs) }\end{array}$ & $\begin{array}{l}\text { Cases } \\
\text { (add) }\end{array}$ & $\begin{array}{l}\text { Deaths } \\
(\exp )^{\text {a }}\end{array}$ & $\begin{array}{l}\text { Deaths } \\
\text { (obs) }\end{array}$ & $\begin{array}{l}\text { Cases } \\
\text { (add) }\end{array}$ & $\begin{array}{l}\text { Deaths } \\
(\exp )^{\text {a }}\end{array}$ \\
\hline $\begin{array}{l}\text { Sutherland } \\
1959(8) \\
\text { [tbl. } 10 \& 9]\end{array}$ & 2355 & 5 years & $\begin{array}{c}\text { Employed } \\
1925-1957\end{array}$ & $\begin{array}{c}1930-1957 \\
(28)\end{array}$ & $\begin{array}{l}\text { Company insurance } \\
\text { records; municipal } \\
\text { registries; provincial } \\
\text { mortality files }\end{array}$ & 19 & .. & 8.5 & 7 &.. & 0.19 \\
\hline $\begin{array}{l}\text { Sutherland } \\
1959(8) \\
\text { [tbl. 18 \& 17] }\end{array}$ & 2355 & 5 years & $\begin{array}{c}\text { Employed } \\
1925-1957\end{array}$ & $\begin{array}{c}1930-1959 \\
(30)\end{array}$ & same as above & 21 & 1 &.. & 11 & 1 &.. \\
\hline $\begin{array}{l}\text { Mastromatteo } \\
1967 \text { (9) } \\
{[\text { Tbl. 4] }}\end{array}$ & 2355 & 5 years & $\begin{array}{l}\text { Employed } \\
1925-1957\end{array}$ & $\begin{array}{c}1930-1965 \\
(36)\end{array}$ &.. & 37 &.. & 12.7 & 16 &.. & 0.17 \\
\hline $\begin{array}{l}\text { NIOSH } 1977 \\
\text { (44) [Tbl. } \\
\text { III-7] }\end{array}$ & 2328 & 5 years & $\begin{array}{c}\text { Employed } \\
1925-1957\end{array}$ & $\begin{array}{c}1930-1974 \\
(45)\end{array}$ &.. & 76 &.. & 41.0 & 24 &.. & 0.47 \\
\hline $\begin{array}{l}\text { NIOSH } 1977 \\
\text { (44) [Tbl. } \\
\text { XV-4 \& XV-3] }\end{array}$ & 2328 & 5 years & $\begin{array}{c}\text { Employed } \\
1925-1957\end{array}$ & $\begin{array}{c}\text { 1930-June } 1976 \\
(46.5)\end{array}$ &.. & $82^{b}$ & 8 &. & $29 c$ & 7 &.. \\
\hline $\begin{array}{l}\text { Roberts et } \\
\text { al } 1984 \text { (28) } \\
\text { [Tbl. 2] }\end{array}$ & 4288 & $\begin{array}{l}1 \text { day in LCS } \\
\text { or } 6 \text { months } \\
\text { elsewhere }\end{array}$ & $\begin{array}{l}\text { Alive on } \\
1 \text { Jan }\end{array}$ & $\begin{array}{l}\text { 1950-Dec } \\
1976(27)\end{array}$ & $\begin{array}{l}\text { Company benefits } \\
\text { records; Canadian National } \\
\text { Mortality Database }\end{array}$ & $62^{d}$ &.. & $33.1 d$ & $17^{\mathrm{d}, \mathrm{e}}$ &.. & $0.33^{d}$ \\
\hline $\begin{array}{l}\text { Roberts et } \\
\text { al 1989 (29) } \\
\text { [Tbl. 2] }\end{array}$ & 4287 & $\begin{array}{l}1 \text { day in LCS } \\
\text { or } 6 \text { months } \\
\text { elsewhere }\end{array}$ & $\begin{array}{l}\text { Employed or } \\
\text { pensioner in Jan } \\
1950 \text { or later }\end{array}$ & $\begin{array}{c}1950-1984 \\
(35)\end{array}$ & same as above & 104 &.. & 65.5 & 19 &.. & 0.56 \\
\hline $\begin{array}{l}\text { Doll et al } \\
\text { 1990, ICNCM } \\
\text { (13) } \\
\text { [Tbl. } 49 \& 53]\end{array}$ & 4288 & $\begin{array}{l}1 \text { day in LCS } \\
\text { or } 6 \text { months } \\
\text { elsewhere }\end{array}$ & $\begin{array}{l}\text { Employed or } \\
\text { pensioner in Jan } \\
\text { or later }\end{array}$ & $\begin{array}{c}1950-1984 \\
(35)\end{array}$ & same as above & $103^{d}$ &.. &.. & $19^{d}$ &.. &.. \\
\hline $\begin{array}{l}\text { Roberts et } \\
\text { al 1992 (43) } \\
\text { [Tbl. 48.1 \& } \\
\text { 48.7] } \\
\end{array}$ & 4287 & $\begin{array}{l}1 \text { day in LCS } \\
\text { or } 6 \text { months } \\
\text { elsewhere }\end{array}$ & $\begin{array}{l}\text { Employed or } \\
\text { retired by } 1 \text { Jan } \\
1950 \text { or later }\end{array}$ & $\begin{array}{c}1950-1984 \\
(35)\end{array}$ & same as above & 104 &.. & 65.5 & 19 &.. & 0.56 \\
\hline \multicolumn{12}{|c|}{$\begin{array}{l}\text { a Derived from provincial rates (Ontario). } \\
\text { b Two lung cancer deaths occurred in } 1946 \text { and } 1949 \text {, respectively; the eight living lung cancer patients were diagnosed 1961-1973; all deaths and } \\
\text { diagnoses occurred } \geq 15 \text { years after first employment. } \\
\text { c Two nasal cancer deaths occurred in } 1946 \text { and 1948, respectively; the seven living nasal cancer patients were diagnosed 1966-1973; all deaths and } \\
\text { diagnoses occurred } \geq 15 \text { years after first employment. } \\
\text { d Cancers occurring } \geq 15 \text { years after first employment. } \\
\text { e Roberts et al } 1984 \text { (28) reported } 17 \text { deaths in table } 2 \text { with corresponding expected numbers; Roberts et al } 1984 \text { (28) reported } 18 \text { deaths in table } 4 \text { with } \\
\text { no expected values. }\end{array}$} \\
\hline
\end{tabular}

In 1976, the PCNR employer (International Nickel Company or Inco), submitted data (15) to NIOSH to assist their work with standards for occupational exposure to nickel (44). The data contained updated cancer mortality for the original cohort through June 1976 and case series of lung cancer and nasal cancer, with detailed and revised individual data on length of employment in seven departments.

NIOSH categorized each worker with respiratory cancer according to the department where he had served the longest (44) - an approach strikingly similar to the first paper on cancer among Norwegian nickel refiners from 1973 (12). NIOSH noted that one fourth of the nasal cancer deaths at PCNR occurred among workers with their longest service in the electrolysis department, as did $23 \%$ of the deaths from lung cancer. The numbers of expected deaths were not reported for the relevant subgroups, but NIOSH stated that "all nickel-refinery workers may have an increased risk" [(44) p85], another striking similarity to the first Norwegian cancer report (12).

\section{Port Colborne studies after 1980}

In the wake of this alarming NIOSH message, a new enlarged study was announced (47), eventually to include $>54000$ Inco workers in Ontario, Canada. They were potentially exposed to nickel in mines, smelters, and refineries and were required to have, as a minimum, one single day's experience at a dusty sinter plant, alternatively $\geq 6$ months elsewhere in the company. The new cohort included nearly 4290 workers from PCNR, up some 1950 from the original cohort. Still, the new 
Table 3. Lung cancer mortality 1950-1984 among Copper Cliff copper-refinery workers, Canada. All deaths were observed $\geq 15$ years after first exposure. [exp=expected; ICNCM=International Committee on Nickel Carcinogenesis in Man; obs=observed; SMR=standardized mortality ratio]

\begin{tabular}{|c|c|c|c|c|c|c|c|c|c|}
\hline $\begin{array}{l}\text { Data source } \\
\text { article/report } \\
\text { [table] }\end{array}$ & $\begin{array}{l}\text { Number; } \\
\text { type } \\
\text { of worker }\end{array}$ & $\begin{array}{l}\text { Minimum } \\
\text { employment }\end{array}$ & $\begin{array}{l}\text { Qualification } \\
\text { period }\end{array}$ & $\begin{array}{l}\text { Follow- } \\
\text { up period } \\
\text { (years) }\end{array}$ & $\begin{array}{l}\text { Outcome } \\
\text { source }\end{array}$ & $\begin{array}{l}\text { Subgroup } \\
\text { (length of } \\
\text { employment) }\end{array}$ & $\begin{array}{l}\text { Deaths } \\
\text { (obs) }\end{array}$ & $\begin{array}{l}\text { Deaths } \\
(\exp )\end{array}$ & $\begin{array}{c}\text { SMR } \\
\text { (obs/exp) }\end{array}$ \\
\hline $\begin{array}{l}\text { Ontario Department } \\
\text { of Health } 1971 \text { (32) } \\
\text { [Tbl. 14] }\end{array}$ & $\begin{array}{l}\text { 76; tank-house } \\
\text { workers only }\end{array}$ & 5 years & $\begin{array}{l}\text { 1946-1967, } \\
\text { active worker } \\
\text { by } 1950\end{array}$ & $\begin{array}{c}1950-1967 \\
(18)\end{array}$ & $\begin{array}{l}\text { Company insurance } \\
\text { records; Municipal } \\
\text { registries; Provincial } \\
\text { mortality files }\end{array}$ & $\geq 15$ years & 3 & 0.83 & 3.6 \\
\hline $\begin{array}{l}\text { Doll et al 1990, } \\
\text { ICNCM (13) } \\
\text { [Tbl. 59] }\end{array}$ & $\begin{array}{l}\text { 3124; tank-house } \\
\text { and furnace, } \\
\text { non-sinter }\end{array}$ & 0.5 years & $\begin{array}{l}\text { Employed or } \\
\text { pensioner } 1 \\
\text { Jan } 1950 \text { or } \\
\text { later }\end{array}$ & $\begin{array}{c}1950-1984 \\
(35)\end{array}$ & $\begin{array}{l}\text { Company benefits } \\
\text { records; Canadian National } \\
\text { Mortality Database }\end{array}$ & $\begin{array}{l}\text { Any } \\
\text { duration }\end{array}$ & 48 & 36.6 & 1.3 \\
\hline $\begin{array}{l}\text { Doll et al 1990, } \\
\text { ICNCM (13)[Tbl. 59] }\end{array}$ & $\begin{array}{l}\text { same as } \\
\text { above }\end{array}$ & 0.5 years & $\begin{array}{l}\text { same as } \\
\text { above }\end{array}$ & $\begin{array}{c}1950-1984 \\
(35)\end{array}$ & same as above & 5-24 years & 13 & 13.8 & 0.9 \\
\hline $\begin{array}{l}\text { Doll et al 1990, } \\
\text { ICNCM (13)[Tbl. 59] }\end{array}$ & $\begin{array}{l}\text { same as } \\
\text { above }\end{array}$ & 0.5 years & $\begin{array}{l}\text { same as } \\
\text { above }\end{array}$ & $\begin{array}{c}1950-1984 \\
(35)\end{array}$ & same as above & $\geq 25$ years & 24 & 11.6 & 2.1 \\
\hline $\begin{array}{l}\text { Roberts et al } 1992(43) \\
\text { [Tbl. 48.6] }\end{array}$ & $\begin{array}{l}\text { Tank-house and } \\
\text { furnace (ever), } \\
\text { non-sinter }\end{array}$ & 0.5 years & $\begin{array}{l}\text { same as } \\
\text { above }\end{array}$ & $\begin{array}{c}1950-1984 \\
(35)\end{array}$ & same as above & $\begin{array}{c}\text { Any } \\
\text { duration }\end{array}$ & 50 & 36.3 & 1.4 \\
\hline $\begin{array}{l}\text { Derived from Roberts } \\
\text { et al } 1992(43) \\
\text { [Thl. 48.6] }\end{array}$ & $\begin{array}{l}\text { same as } \\
\text { above }\end{array}$ & 0.5 years & $\begin{array}{l}\text { same as } \\
\text { above }\end{array}$ & $\begin{array}{c}1950-1984 \\
(35)\end{array}$ & same as above & $<25$ years & 24 & 23.0 & 1.0 \\
\hline $\begin{array}{l}\text { Roberts et al } 1992(43) \\
\text { [Tbl. 48.6] }\end{array}$ & $\begin{array}{l}\text { same as } \\
\text { above }\end{array}$ & 0.5 years & $\begin{array}{l}\text { same as } \\
\text { above }\end{array}$ & $\begin{array}{c}1950-1984 \\
(35)\end{array}$ & same as above & $\geq 24$ years & 26 & 13.3 & 2.0 \\
\hline $\begin{array}{l}\text { Verma et al } 1992 \\
\text { (34) [Tbl. I] }\end{array}$ & $\begin{array}{l}\text { Tank-house and } \\
\text { furnace (ever), } \\
\text { non-sinter }\end{array}$ & 0.5 years & $\begin{array}{l}\text { same as } \\
\text { above }\end{array}$ & $\begin{array}{c}1950-1984 \\
(35)\end{array}$ & same as above & $<5$ years & 11 & 11.2 & 1.0 \\
\hline $\begin{array}{l}\text { Verma et al } 1992 \\
\text { (34) [Tbl. I] }\end{array}$ & $\begin{array}{l}\text { Tank-house and } \\
\text { furnace (ever), } \\
\text { non-sinter }\end{array}$ & 0.5 years & $\begin{array}{l}\text { same as } \\
\text { above }\end{array}$ & $\begin{array}{c}1950-1984 \\
(35)\end{array}$ & same as above & $\geq 5$ years & 39 & 25.3 & 1.5 \\
\hline $\begin{array}{l}\text { Verma et al } 1992 \\
\text { (34) [Tbl. I] }\end{array}$ & Lead welders (ever) & 0.5 years & $\begin{array}{l}\text { same as } \\
\text { above }\end{array}$ & $\begin{array}{c}1950-1984 \\
(35)\end{array}$ & same as above & $<5$ years & 1 & 0.2 & 5.1 \\
\hline $\begin{array}{l}\text { Verma et al } 1992 \\
\text { (34) [Tbl. I] }\end{array}$ & Lead welders (ever) & 0.5 years & $\begin{array}{l}\text { same as } \\
\text { above }\end{array}$ & $\begin{array}{c}1950-1984 \\
(35)\end{array}$ & same as above & $\geq 5$ years & 4 & 0.4 & 11.0 \\
\hline $\begin{array}{l}\text { Verma et al } 1992 \\
\text { (34) [Tbl. I] }\end{array}$ & $\begin{array}{c}\text { Tank-house } \\
\text { cranemen (ever) }\end{array}$ & 0.5 years & $\begin{array}{l}\text { same as } \\
\text { above }\end{array}$ & $\begin{array}{c}1950-1984 \\
(35)\end{array}$ & same as above & $<5$ years & 3 & 1.5 & 2.1 \\
\hline $\begin{array}{l}\text { Verma et al } 1992 \\
\text { (34) [Tbl. I] }\end{array}$ & $\begin{array}{c}\text { Tank-house } \\
\text { cranemen (ever) }\end{array}$ & 0.5 years & $\begin{array}{l}\text { same as } \\
\text { above }\end{array}$ & $\begin{array}{c}1950-1984 \\
(35)\end{array}$ & same as above & $\geq 5$ years & 3 & 0.8 & 3.6 \\
\hline
\end{tabular}

cohort reported substantially fewer respiratory cancer deaths than the last update of the original cohort (table $2)$, indicating a marked loss of long-term workers $(\geq 5$ years) who were known from the earlier studies to have died from respiratory cancer.

The mortality in the new cohort was addressed a second time based on an extended, overlapping observation period, published in four papers $(13,29,43,48)$, whereof three - including that of the ICNCM - focused on respiratory cancer. Some study characteristics and overall results are summarized in table 2 . All reports confirmed the high risks among sinter workers, with a doubled lung cancer SMR and a nasal cancer mortality some 80 times the expected rate (13). The 1990 ICNCM was, however, the only group of authors to recognize some, although weak, evidence of increased risk of respiratory cancer ascribed to soluble nickel, most clearly seen for nasal cancer among workers with electrolysis experience (13).
A large proportion of the 54000 Ontario workers had an unknown vital status by the end of the observation period. By 1976, 44\% of the cohort was lost to followup in this way (28), rising to $57 \%$ in the last update through 1984, although somewhat lower (42\%) for the PCNR fraction of the cohort (48). Deaths identified by linkage to the Canadian National Mortality Database only contributed some $30 \%$ of all deaths in the last study, implying that the proportion identified in company records was substantial. All cohort members "not known to be dead" at the end of follow-up (24 000 and 31000 men through 1976 and 1984, respectively) were assumed to be alive, meaning that unrecognized dead subjects would falsely inflate the numbers of expected deaths throughout the observation period.

The size of this potential downward bias was addressed in the 1984 study (28), and referred to in the subsequent update (48), by an attempt to trace 
Table 4. Observed nasal cancer deaths and living patients among long-term workers at Port Colborne nickel refinery by original exposure groups, according to original and revised histories of work experience. [NIOSH=US National Institute of Occupational Safety and Health]

\begin{tabular}{|c|c|c|c|c|c|c|c|}
\hline $\begin{array}{l}\text { Exposure groups according } \\
\text { to Sutherland } 1959(8) \text { and } \\
\text { Mastromatteo } 1967 \text { (9) }\end{array}$ & $\begin{array}{c}\text { Deaths } \\
1930-1957 \\
\text { first version } \\
1959 \\
\end{array}$ & $\begin{array}{l}\text { Deaths } \\
1930-1957 \\
\text { revised } 1959\end{array}$ & $\begin{array}{c}\text { Cases and } \\
\text { deaths } 1930- \\
1959, \text { revised } \\
1959\end{array}$ & $\begin{array}{c}\text { Cases and } \\
\text { deaths 1930- } \\
\text { 1959, revised } \\
2011\end{array}$ & $\begin{array}{l}\text { Deaths } \\
1930-1965 \\
1967 \text { data }\end{array}$ & $\begin{array}{c}\text { Cases and } \\
\text { deaths } \\
\text { 1930-1965, } \\
\text { revised 2011 } \\
\end{array}$ & $\begin{array}{c}\text { All reported } \\
\text { cases and deaths } \\
\text { 1930-June 1976, } \\
\text { revised } 2011 \\
\end{array}$ \\
\hline Furnace group ( $\geq 5$ years) & 1 & 0 & 3 & $7^{\text {a }}$ & 5 & $7^{\text {a }}$ & 9 a \\
\hline Other dust ( $\geq 5$ years) & 0 & 0 & 0 & 0 & 0 & 0 & 0 \\
\hline Electrolytic ( $\geq 5$ years) & 0 & 0 & 0 & $1^{\mathrm{b}}$ & 0 & $1^{\mathrm{b}}$ & $3^{b, c}$ \\
\hline $\begin{array}{l}\text { Other non-exposure/ } \\
\text { non-dust ( } \geq 5 \text { years) }\end{array}$ & 0 & 0 & 0 & 0 & 0 & 0 & $1^{d}$ \\
\hline Office ( $\geq 5$ years) & 0 & 0 & 0 & 0 & 0 & 0 & 0 \\
\hline $\begin{array}{l}\text { Mixed ( }<3 \text { years in furnace \& } \\
\text { other dust groups \& other work) }\end{array}$ & 1 & 1 & 1 & $1^{\mathrm{e}}$ & 2 & $2^{e, f}$ & $5^{e, f, g}$ \\
\hline $\begin{array}{l}\text { Mixed ( } \geq 3 \text { years in furnace } \\
\text { group \& other work) }\end{array}$ & 4 & 5 & 7 & 2 & 8 & $8^{\mathrm{h}}$ & $17^{\mathrm{h}, \mathrm{i}}$ \\
\hline $\begin{array}{l}\text { Mixed ( } \geq 3 \text { years in other dust } \\
\text { group \& other work) }\end{array}$ & 1 & 1 & 1 & $1^{\mathrm{j}}$ & 1 & $1^{i}$ & $1^{i}$ \\
\hline Total & 7 & 7 & 12 & 12 & 16 & 19 & 36 \\
\hline Ever furnace worker & 6 & 6 & 11 & 11 & 15 & 18 & 32 \\
\hline Never furnace worker & 1 & 1 & 1 & 1 & 1 & 1 & 4 \\
\hline Data source & $\begin{array}{l}\text { Sutherland } \\
1959(8) \\
{[\text { Table 9] }}\end{array}$ & $\begin{array}{l}\text { Sutherland } \\
1959(8) \\
\text { [Table 17] }\end{array}$ & $\begin{array}{l}\text { Sutherland } \\
1959(8) \\
\text { [Table 17] }\end{array}$ & $\begin{array}{l}\text { NIOSH } 1977 \\
(44) \\
{[\text { Table XV-3] }}\end{array}$ & $\begin{array}{c}\text { Mastromatteo } \\
1967(9) \\
{[\text { Table 4] }}\end{array}$ & $\begin{array}{l}\text { NIOSH } 1977 \\
(44) \\
\text { [Table XV-3] }\end{array}$ & $\begin{array}{l}\text { NIOSH } 1977 \\
(44) \\
\text { [Table XV-3] }\end{array}$ \\
\hline
\end{tabular}

a Four workers had furnace experience only, and 3 workers had furnace experience combined with $\leq 6$ months in "non-dust" departments.

b One worker had 14.8 years in electrolysis and no additional experience other than 6 months in "non-dust" departments.

c One worker had 36.6 years in electrolysis only; and one had 39.4 years in electrolysis and 1.6 years in "non-dust" departments.

d One worker served 21.8 years as a carpenter.

${ }^{e}$ One worker had 16.8 years in electrolysis, 1.7 years in furnace, and 0.1 years in other dust departments.

f One worker had 7.3 years in electrolysis, 14 years in "non-dust" departments, and 0.9 years in furnace.

${ }^{9}$ One worker had 38 years in electrolysis and 0.3 years in furnace; one had 21 years in electrolysis and 0.2 years in furnace; and one had 1.1 years in

furnace and 4.8 years in "nondust" departments.

h Seven workers had $\geq 10$ years in furnace, and another worker had 7.3 years in furnace and 13.7 years in electrolysis.

i Three workers had longer employments in Electrolysis (25.5, 21.3, and 13.7 years) than in Furnace (4.5, 12, and 7.3 years, respectively)

i One worker had 6.3 years in Electrolysis, 15.8 years in Other dust, and 1.1 years in Furnace.

individually 1000 men out of the 24000 not found to be dead in company records. The results showed that $75(7.5 \%)$ out of the 1000 men were completely lost to follow-up as a result of emigration or unknown reason despite reinforced efforts. Among the 1000, 9 deaths were revealed by tracing only, and should, for a better correspondence with the expected numbers, be added to the 58 deaths recognized by linkage to the National Mortality Database. Thus, groups unavailable for follow-up in company files should have increased their observed number of deaths by $\geq 15 \%(67 / 58=1.15)$, as some more deaths may have occurred among the 75 that were never found.

\section{Copper Cliff copper refinery studies}

A 1971 report from Ontario health authorities addressed selected groups of non-sinter workers at CCCR and presented cancer mortality for the period 1950-1967
(32). In a subgroup of 76 copper tank-house workers, those with $\geq 15$ years of service showed 3 lung cancer deaths against 0.83 expected, suggesting an elevated SMR of 3.6 (95\% confidence interval $0.75-11$, assuming a Poisson distribution of the observed deaths) (table 3). The suggested excess was noted by NIOSH in 1977 (44).

More than 3000 men with service from the CCCR (furnace and electrolysis departments) were later included in the large studies of potentially nickelexposed Ontario workers published after 1980 (13). Within a copper-refinery subgroup with $\geq 25$ years of work experience, lung cancer mortality was twice that expected (table 3) $(13,29)$. Most of the excess, which was assumed to be work-related, was identified among workers from the tank-house, notably among lead welders and crane men, the latter handling electrodes from travelling cranes above the electrolytic tanks $(29,34)$. 


\section{Discussion}

Given similar routines and performance of the work, the process descriptions from the PCNR electrolysis department support the assumption made by the ICNCM that exposure to water-soluble nickel was lower in the PCNR compared to the Norwegian nickel electrolysis department. The potential for exposure to soluble nickel at the CCCR, and its possible contribution to the observed work-related increase in lung cancer, have not, to our knowledge, been addressed in any earlier paper. We found no data on cancer mortality after 1984 for any of the two refineries, although production continued until 1984 and 2005 at PCNR and CCCR, respectively.

For the PCNR cancer studies after 1980, a substantial loss of long-term workers and respiratory cancer deaths was detected, apparently caused by changes in inclusion criteria that were poorly described. The new PCNR cohort formed part of an extended cohort of nickel exposed workers, of whom $57 \%$ had unknown vital status at the end of the most recent mortality follow-up. Mortality estimates were strongly dependent on company data. The numbers of deaths identified merely by linkage to national registries should have been $15 \%$ higher than reported. Only the ICNCM study presented cross-tables that were appropriate for identification of risk associated with exposure to water-soluble nickel compounds.

\section{Changes in cohort definitions}

Around 1980, the exclusion of long-term workers in the PCNR cohort must have led to a critical loss of information as well as a reduction of statistical power. The transition has been inadequately and inconsistently reported in articles after 1980.

The first post-1980 study from 1984, which was reviewed and cited by the US Environmental Protection Agency (EPA) two years later [(45) p8-25], stated that the new large cohort included workers who were "alive on or after January 1, 1950" [(28) p25]. If correct, we would expect to find all but four of the 111 respiratory cancer deaths among long-term workers ( $\geq 5$ years) recorded by NIOSH in 1977 (44), omitting only two nasal cancer deaths and two lung cancer deaths because they occurred before 1950 (table 2). By contrast, only 79 respiratory cancer deaths were reported, down 28 (26\%) from the 107 relevant ones listed by NIOSH.

A similar drop was seen in the expected numbers of deaths. Consequently, the decline was not merely a result of unsuccessful record-linkage or erroneous diagnoses but rather a real loss, or exclusion, of longterm workers who had a higher age than the new cohort
Table 5. Nasal cancer cases $(\mathrm{N}=5)$ and deaths $(\mathrm{N}=17)$ among Port Colborne nickel-refinery workers active a by 1950 or later, with some experience in leaching, calcining, and sintering (LCS) departments, according to length of employment in LCS departments and in electrolysis (44).

\begin{tabular}{lcccccccc}
\hline $\begin{array}{l}\text { Length of } \\
\text { employment } \\
\text { in electrolysis }\end{array}$ & \multicolumn{6}{c}{ Length of employment in LCS departments (in years) } \\
\cline { 2 - 8 } & $\begin{array}{c}b \\
0.003^{c}-\end{array}$ & $2-4.9$ & $5-9$ & $10-14$ & $15-19$ & $\geq 20$ & $\begin{array}{c}\text { Any } \\
\text { length }\end{array}$ \\
\hline $0-1.9$ years & 1 & 0 & 2 & 2 & 3 & 6 & 14 \\
$2-4.9$ years & 0 & 0 & 0 & 0 & 1 & 1 & 2 \\
$5-9$ years & 0 & 0 & 0 & 0 & 1 & 0 & 1 \\
$10-14$ years & 0 & 0 & 1 & 0 & 0 & 0 & 1 \\
$15-19$ years & 0 & 0 & 0 & 0 & 0 & 0 & 0 \\
$\geq 20$ years & 2 & 1 & 0 & 1 & 0 & 0 & 4 \\
Any length & 3 & 1 & 3 & 3 & 5 & 7 & 22 \\
\hline
\end{tabular}

a "Active" workers judged by year of first employment and total number of years employed.

' LCS employment computed as the sum of years in "calciner", "sinter" and "other dust" departments, the latter including leaching activities, as reported by US National Institute of Occupational Safety and Health (NIOSH) [(44), Table XV-3].

c Workers with as little as 1 day employment in the LCS departments qualified for inclusion in the cohort established in the late 1970s (28).

members that replaced them (table 2). Both the early studies and the post-1980 studies relied on similar sources of mortality outcome, namely a combination of company files and population mortality registries (local, provincial, or national), and they seem, in this respect, largely comparable.

By the second update of the post-1980 PCNR cohort, the number of cohort members remained the same, although somewhat more narrow inclusion criteria were reported, as the subjects were claimed to have "worked (or been a pensioner) between January 1950 and December 31, 1976" [(48) p961; (13) p19]. Another even more constricted criterion was suggested by the ICNCM, leaving out the option of being a pensioner [(13) p11, footnote to table 1]. Still, the inconsistencies seem to remain in the number of deaths, as NIOSH, in 1977 (44), listed 22 nasal cancer deaths among workers who were actively working, long-term employees by 1950 or later - judged individually by year of first employment and the total number of years employed - against the overall 17 or 18 nasal cancer deaths recorded in the first post-1980 paper with a slightly longer follow-up (table 2) (28).

Data from the Workmen's Compensation Board of Ontario (WCBO) reported 36 cases and deaths of nasal cancer (combined) between 1947 and 1979 from PCNR (49). Interestingly, the eight extra observation years (1977-1984) for the second update of the extended PCNR cohort produced only one additional nasal cancer death (table 2) $(13,29)$. This is somewhat surprising given that the old cohort of long-term workers during the 
preceding three 8-year periods (1953-1960, 1961-1968, and 1969-1976) produced 12,7 , and 15 cases or deaths from nasal cancer, respectively [(44) p277, table XV-3]. Experience from Welsh refiners indicated that the risk of nasal cancer lasted 15-42 years "after the carcinogen was eliminated" (10). At PCNR, the sintering activity was associated with the highest risks and was terminated in 1958 (28), allowing only 26 years of follow-up (through 1984) after elimination of the exposure (13, 29). The WCBO data for PCNR reported an average of 33.5 years from first exposure to nasal cancer diagnosis, ranging from 15-47 years (49).

Unless a reasonable explanation is provided, this loss of long-term workers and respiratory cancer deaths and the limited follow-up seriously question the reliability of the data reported from the PCNR after 1980. Evidence from Norwegian electrolysis workers point to the highest lung cancer risks among workers with $\geq 15$ years' experience (24), and the loss of statistical power may very well have affected the risk assessment for groups with more moderate exposures. An additional selection bias could, of course, be detrimental. We found neither an explanation for the loss of data nor any review to discuss the problem [searching in the US EPA 1986 health assessment document (45), the IARC 1990 mongraph (1), the Toxicology Excellence for Risk Assessment (TERA) toxicological review of soluble nickel salts prepared in 1999 (30), and the review sponsored by nickel producers in 2009 (19)].

\section{Lack of focus on soluble nickel}

A moderate risk associated with electrolysis work need not emerge in a study with focus on the effect of heavy exposures to nickel subsulphide among sinter workers, as was the case - according to the authors - in the PCNR studies after 1980 [(28) p24; (29) p977]. Their approach contrasts the original challenge in the statement from NIOSH that all refiners might be at risk (44). The cancer mortality was largely displayed in tables with a single explanatory variable, most often duration of sinter work, an approach that easily may have masked an effect from electrolysis exposure.

The 1984 report claimed that the risk of nasal cancer increased after very short exposure in leaching, calcining, and sintering (LCS) activity (28). We used the 1977 NIOSH case series of nasal cancers from approximately the same observation period (44) to distribute the workers with some LCS experience according to time spent in the electrolysis and LCS departments. For this purpose "length of employment in LCS" was computed as the sum of years in calcining, sintering, and "other dust" departments, the latter including leaching activities (8). Our results in table 5 illustrate the acknowledged strong effect from exposure in the LCS departments, but the data also indicate a separate effect among longterm electrolysis workers, left unnoticed throughout the 1980 s by the authors and by the US EPA $(28,29,45)$.

In the 1992 article, a table with 19 nasal cancer deaths was published, still with LCS experience as the only explanatory variable [(43) p641, table 48.8], although the ICNCM, two years earlier and from the same data, showed that 13 out of the 19 men, indeed, had experience in electrolysis work, 7 of them for $\geq 15$ years [(13) p56, table 55].

For the CCCR, the risk of lung cancer among longterm workers in the tank-house increased with duration of employment and was thus assumed to be workrelated. The presence or concentration of soluble nickel in the electrolyte $(20 \mathrm{~g} / \mathrm{L})$ was not communicated, and its possible contribution to the cancer excess was not discussed, neither in the epidemiological articles $(13,29$, 43) nor in the industrial hygiene report (34). The latter focused on PAH exposure.

\section{Loss to follow-up}

The mortality studies after 1980 reported a high number of men with unknown vital status by the end of followup, and the number increased from the first to the second update. The failure to recognize deaths, and the inflated number of expected deaths, would be at their maximum in the second, extended, and most recent update, biasing the observed-to-expected SMR downwards for important evaluations, such as the 1990 report of the ICNCM (13) and the IARC evaluation from the same year (1).

For the whole 54000 -worker cohort, a substantial proportion (70\%) of deaths was found in company records, and - given that the company data were complete and correct - an overall $5 \%$ underestimation in the SMR was suggested in 1976 (28). Loss to follow-up was less pronounced for the PCNR part of the cohort, as $42 \%$ had unknown vital status, and $80 \%$ of deaths were recorded in company records (48). On the other hand, a higher age of PCNR workers was suggested in the data (48), which may increase the risk of a downward bias. The bias may also be stronger for short-term workers, for whom the recognition of a death would be more dependent on a successful linkage to the National Mortality Database. An underestimation of the risk would easily be tolerated for a group with a large cancer excess, while the bias may be disturbing for moderately exposed workers.

The limitations associated with incomplete followup, could possibly have been helped, at least in later years, with other approaches in design, such as proportionate mortality analyses, regression analyses performed within the cohort, or nested case-control studies with an improved tracing of randomly drawn controls. No such analyses were found. 


\section{Awareness of old data}

In the early PCNR reports from 1959 and 1967, no nasal cancer death was reported among long-term electrolysis workers $(8,9)$. The most recent update of this original cohort - the one submitted by the employer and presented by NIOSH in the 1977 nickel criteria document $(15,44)$ - did, however, include one death from nasal cancer in 1946 of a worker earlier assigned with "mixed exposure", but, by 1976-1977, described as having experienced 15 years in the electrolysis and 0.5 years in no-dust departments (table 6, case 11). This worker may represent the earliest sign of a nasal cancer risk among nickel-exposed Canadian electrolysis workers.

Furthermore, the 1976 report from the employer stated in larger detail: "A review of the sinus cancer cases at PCNR reveals nine cases with electrolytic exposure that do not meet this arbitrary minimum condition [of $\geq 1$ year work experience, authors' comment] for attribution to sintering or calcining. Three of these cases had no apparent exposure to any furnace operation or other dusty job." [(15) p32].

In table 6, we list 7 deaths and one case of nasal cancer taken from the NIOSH 1977 criteria document, all men with no experience in LCS departments (44). The ICNCM, on the other hand - based on the incomplete post-1980 cohort - reported no such death in the same exposure group between 1950 and 1984 [(13) p52, table 49]. Referring to the US EPA 1986 health assessment document (45), the ICNCM wrote that "previous analyses have indicated an absence of lung and nasal cancer risk among the Port Colborne electrolysis workers, in contrast to the evidence of risk related with soluble nickel at Kristiansand" [(13) p55]. The 1976 report from the employer, and the case series presented by NIOSH in 1977 based on the same data, demonstrated that evidence of a nasal cancer risk among PCNR electrolysis workers did, in fact, exist $(15,44)$.

It may also be of interest to recall the notice by NIOSH that $25 \%$ of the nasal cancer deaths at PCNR occurred among long-term electrolysis workers and that a similar distribution existed for lung cancer deaths (23\% among long-term electrolysis workers) (44). Both diseases were in excess in the overall PCNR cohort, and the similarity of the distribution would fit with a risk of both types of cancer in the electrolysis.

The nasal cancer evidence from NIOSH in 1977 (table 6) also undermines the statement from 2008 in the Nickel Institute's Safe Use of Nickel in the Workplace guide: "While nasal cancers were seen in a few of the Canadian electrolysis workers, these particular workers had also worked in sintering departments where exposures to sulfidic and oxidic nickel were very high $(>10$ $\left.\mathrm{mg} \mathrm{Ni} / \mathrm{m}^{3}\right)$ " [(18) p41]. A similar statement of "no nasal cancers" observed among PCNR electrolysis workers with no experience from LCS was provided in a review sponsored by nickel producers in 2009 [(19) p376].

At CCCR, crane men and lead welders in the tankhouse were found to have a risk of lung cancer that increased with length of employment (table 3) (34). The crane men worked with hoisting and submersion of racks of electrodes from a position above tanks that held warm $\left(60^{\circ} \mathrm{C}\right)$ electrolyte with $20 \mathrm{~g}$ soluble nickel per liter. The welders worked with materials contaminated with soluble nickel salts, on tank linings, and with piping for transport of electrolyte. The first suspicion of a hazard in the copper tank-house appeared in 1971 (32), reinforced by a report by union members in the early 1980s (cited in 34). Still, around 1990, the lung cancer excess among long-term tank-house workers was termed "unexpected" and "unanticipated", a result

Table 6. Employment histories of Port Colborne nickel-refinery workers with nasal cancer and no exposure in the leaching, calcining, and sintering (LCS) departments [(44) table XV-3].

\begin{tabular}{|c|c|c|c|c|c|c|c|c|c|c|c|c|c|}
\hline \multirow{3}{*}{$\begin{array}{l}\text { Case number, } \\
\text { from NIOSH, } \\
1977 \text { (44) }\end{array}$} & \multirow{3}{*}{$\begin{array}{l}\text { First year of } \\
\text { employment }\end{array}$} & \multirow{3}{*}{$\begin{array}{l}\text { Year of } \\
\text { death }\end{array}$} & \multirow{3}{*}{$\begin{array}{l}\text { Year of } \\
\text { diagnosis }\end{array}$} & \multirow{3}{*}{$\begin{array}{c}\text { Total } \\
\text { employment } \\
\text { (years) }\end{array}$} & \multicolumn{8}{|c|}{ Length of employment in departments (years) } & \multirow{3}{*}{$\begin{array}{l}\text { Dept. of } \\
\text { longest } \\
\text { exposure }\end{array}$} \\
\hline & & & & & \multicolumn{4}{|c|}{ Furnace } & \multirow[t]{2}{*}{ Electrolysis } & \multirow{2}{*}{$\begin{array}{l}\text { Other } \\
\text { dust }\end{array}$} & \multirow{2}{*}{$\begin{array}{c}\text { Not } \\
\text { dusty }\end{array}$} & \multirow[t]{2}{*}{$\operatorname{LCS}^{\text {a }}$} & \\
\hline & & & & & Cupola & Calciner & Sinter & Anode & & & & & \\
\hline 21 & 1930 & 1975 & & 41.0 & 0.0 & 0.0 & 0.0 & 0.0 & 39.4 & 0.0 & 1.6 & 0 & Electrolysis \\
\hline 22 & 1931 & 1969 & & 36.6 & 0.0 & 0.0 & 0.0 & 0.0 & 36.6 & 0.0 & 0.0 & 0 & Electrolysis \\
\hline 2 & 1922 & 1962 & & 41.9 & $21.5^{b}$ & 0.0 & 0.0 & 0.0 & 20.4 & 0.0 & 0.0 & 0 & Cupola \\
\hline 11 & 1928 & 1946 & & 15.3 & 0.0 & 0.0 & 0.0 & 0.0 & 14.8 & 0.0 & 0.5 & 0 & Electrolysis \\
\hline 5 & 1923 & 1963 & & 22.2 & 0.9 & 0.0 & 0.0 & 0.0 & 7.3 & 0.0 & 14.0 & 0 & Not dusty \\
\hline 29 & 1936 & & 1973 & 6.9 & 0.0 & 0.0 & 0.0 & 1.1 & 1.0 & 0.0 & 4.8 & 0 & Not dusty \\
\hline 10 & 1926 & 1973 & & 37.2 & 0.0 & 0.0 & 0.0 & 37.2 & 0.0 & 0.0 & 0.0 & 0 & Anode \\
\hline 33 & 1942 & 1972 & & $28.1^{c}$ & 0.0 & 0.0 & 0.0 & 0.0 & 0.0 & 0.0 & 21.8 & 0 & Not dusty \\
\hline
\end{tabular}

a LCS, calculated as the sum of years in "calciner", "sinter", and "other dust" departments, the latter inclusive of leaching activities (8).

b This worker was employed at the Inco facility in Bayonne, NJ (USA).

c This workers was a carpenter. In the original report from the employer (15), he was recorded with 21.8 years in "not dusty" departments only, and the total length of employment of "28.1" years shown in the present table, was taken from the US National Institute of Occupational Safety and Health (NIOSH) criteria document [(44), table XV-3], possibly representing a misprint. 
of "exploratory data analysis" or "routine review" [(29) p991; (34) p317] - statements suggesting a bias or neglect of old data in the interpretation of the results.

The lung cancer excess among CCCR workers appears to be lower than that reported from the Norwegian Kristiansand copper electrolysis, with some doubling of the risk (table 3) compared to a six-fold increase (24) among long-term employees at the two refineries, respectively. Such a difference is in line with an overall lower exposure to soluble nickel compounds at CCCR, as suggested by the process description reported above. No nasal cancer death was observed at the CCCR, which could be explained by a low statistical power $(<0.5$ nasal cancer deaths expected), or even by misclassification of this rare disease. The latter is a recognized problem in the nickel and cancer literature $(28,50)$.

\section{Analytic strategies}

Except for the reports from NIOSH and the ICNCM, risk identification in the two Canadian electrolytic refineries have been performed by defining exposures according to work in a single department or a group of departments. Problems with such classification methods are illustrated in table 4, and today, they could be better handled with multiple regression models. During the last two decades, the use of exposure intensity combined with duration of exposure for the calculation of cumulative exposures has become quite common in occupational epidemiology. It has provided interesting results in the assessment of exposure-related risks among the Welsh (20) and the Norwegian nickel workers $(21,23-25)$. A similar approach for the Canadian electrolytic refineries might have improved the scientific outcome materially and should have been properly tested - although the underlying flaws caused by loss of many long-term workers with respiratory cancer and the high percentage lost to follow-up may also threaten the validity of such analyses unless special measures are taken.

In retrospect, a better description of the historical epidemiological data could have been provided more than 20 years ago, and it might have reinforced the conclusion of 1990 by the ICNCM and the IARC working group in recognizing the carcinogenic properties of soluble nickel compounds.

\section{Concluding remarks}

Most cancer reports that include the two groups of Ontario electrolysis workers have not adequately explored the effects from soluble nickel exposure. The report from the ICNCM did point to a possible excess in the PCNR electrolysis workforce, and the 1977 NIOSH case series contained strong evidence of a nasal cancer risk among electrolysis workers, evidence that has remained unnoticed in later reviews. We must conclude that the alleged absence of an excess of respiratory cancer has resulted from an arbitrary overemphasis of biased and inconclusive findings.

Comparison of old (pre-1980) and new reports from PCNR revealed a serious loss of statistical power and a possible selection bias resulting from exclusion of longterm workers, many of whom were known from earlier reports to have died from respiratory cancer within the follow-up period of the most recent studies. Additionally, the problem with a high proportion of workers with unknown vital status and unrecognized deaths increased over time, resulting in a downward bias at its maximum in the data used by the ICNCM and the IARC working group in 1990. The irregularities in the design and conduct in many of the studies and the restricted length of follow-up have the potential to affect more severely groups of workers with low-to-moderate exposure, as well as short-term employees with no deaths registered in company files.

For CCCR electrolysis workers, exposure to soluble nickel from the electrolyte has been largely disregarded in the epidemiological studies and in the industrial hygiene report, despite its potential to explain, fully or in part, the work-related lung cancer excess seen among long-term employees. The last published follow-up of cancer mortality was terminated 20 years before the plant was abandoned.

\section{Acknowledgements}

The authors have no competing financial interests to declare. No funding was received for this study.

\section{References}

1. International Agency for Research on Cancer (IARC). Chromium, nickel and welding. Lyon: IARC; 1990. IARC monographs on the evaluation of carcinogenic risks to humans, vol 49:257-445. http://monographs.iarc.fr/ENG/ Monographs/vol49/index.php

2. Parliamentary intelligence, House of Commons: Cancer among Welsh nickel workers. Lancet. 1932;219:375. http:// dx.doi.org/10.1016/S0140-6736(00)91005-5.

3. Bridge JC. Annual report of the chief inspector of factories and workshops for the year 1932. London: His Majesty's Stationery Office; 1933.

4. Bridge JC. Annual report of the chief inspector of factories and workshops for the year 1934. London: His Majesty's Stationery Office; 1935.

5. Barnett GP. Annual report of the chief inspector of factories for the year 1948. London: His Majesty's Stationery Office; 1949. 
6. Morgan JG. Some observations on the incidence of respiratory cancer in nickel workers. Br J Ind Med. 1958;15:224-34.

7. Doll R. Cancer of the lung and nose in nickel workers. Br J Ind Med. 1958;15:217-23.

8. Sutherland RB. Respiratory cancer mortality in workers employed in an Ontario nickel refinery 1930-1957. Toronto: Ontario Department of Health, 1959. p154.

9. Mastromatteo E. Nickel: A review of its occupational health aspects. J Occup Med. 1967;9:127-36. http://dx.doi. org/10.1097/00043764-196703000-00010.

10. Doll R, Morgan LG, Speizer FE. Cancer of the lung and nasal sinuses in nickel workers. Br J Cancer. 1970;24:623-32. http:// dx.doi.org/10.1038/bjc.1970.76.

11. International Agency for Research on Cancer (IARC). Some inorganic and organometallic compounds. Lyon: IARC; 1973. IARC monographs on the evaluation of carcinogenic risks to humans, vol 2:126--9.

12. Pedersen E, Høgetveit AC, Andersen A. Cancer of respiratory organs among workers at a nickel refinery in Norway. Int J Cancer. 1973;12:32-41.http://dx.doi.org/10.1002/ ijc. 2910120104 .

13. Doll R, Andersen A, Cooper WC, Cosmatos I, Cragle DL, Easton D et al. Report of the International Committee on Nickel Carcinogenesis in Man. Scand J Work Environ Health. 1990 Feb;16(1 Spec No):1-82.

14. International Agency for Research on Cancer (IARC). A Review of Human Carcinogens. Part C: Arsenic, Metals, Fibres, and Dusts. Lyon: IARC; 2012. IARC monographs on the evaluation of carcinogenic risks to humans, vol 100C:169218 .

15. Nickel and its inorganic compounds (including nickel carbonyl). Unpublished supplementary report submitted to the US National Institute for Occupational Safety and Health (NIOSH) by International Nickel Co Ltd. International Nickel (U.S.) Inc. 1976 Oct. p126. [Available from: US NIOSH, Cincinnati, OH.]

16. Sivulka, DJ. Comments of The Nickel Producers Environmental Research Association (NiPERA), Inc. on the US OSHA's proposed Air Contaminant Rule. OSHA docket H-020, Exhibit 3-668, OSHA-H020-2006-0928-1902. [Hearing document from NiPERA]. 1988 Jul 22. p45. [Available from: http://www.regulations. gov/\#!documentDetail;D=OSHA-H020-2006-0928-1902.]

17. Oller AR, Costa M, Oberdorster G. Carcinogenicity assessment of selected nickel compounds. Toxicol Appl Pharmacol. 1997;143:152-66. http://dx.doi.org/10.1006/taap.1996.8075.

18. Nickel Institute. Safe Use of Nickel in the Workplace, a guide for health maintenance of workers exposed to nickel, its compounds and alloys. Toronto: Nickel Institute, 2008. p124. [Available from: http://www.nickelinstitute.org/en/ /media/ Files/NIPERA/Health\%20Guide\%20Third\%20Edition\%20 June \%202008.ashx]

19. Goodman JE, Prueitt RL, Dodge DG, Thakali S. Carcinogenicity assessment of water-soluble nickel compounds. Crit Rev Toxicol. 2009;39:365-417. http://dx.doi. org/10.1080/10408440902762777.
20. Easton DF, Peto J, Morgan LG, Metcalfe LP, Usher V, Doll R. Respiratory cancer mortality in Welsh nickel refiners: Which nickel compounds are responsible? In: Nieboer E, Nrigau JO, editors. Nickel and Human Health: Current Perspectives. Advances in Environmental Sciences and Technology. New York: John Wiley \& Sons; 1992. p603-19.

21. Andersen A, Berge SR, Engeland A, Norseth T. Exposure to nickel compounds and smoking in relation to incidence of lung and nasal cancer among nickel refinery workers. Occup Environ Med. 1996;53:708-13. http://dx.doi.org/10.1136/ oem.53.10.708

22. Anttila A, Pukkala E, Aitio A, Rantanen T, Karjalainen S. Update of cancer incidence among workers at a copper/nickel smelter and nickel refinery. Int Arch Occup Environ Health. 1998;71:245-50. http://dx.doi.org/10.1007/s004200050276.

23. Grimsrud TK, Berge SR, Haldorsen T, Andersen A. Exposure to different forms of nickel and risk of lung cancer. Am J Epidemiol. 2002;156:1123-32. http://dx.doi.org/10.1093/aje/ kwf165.

24. Grimsrud TK, Berge SR, Martinsen JI, Andersen A. Lung cancer incidence among Norwegian nickel-refinery workers 1953-2000. J Environ Monit. 2003;5:190-7. http://dx.doi. org/10.1039/b211722n.

25. Grimsrud TK, Berge SR, Haldorsen T, Andersen A. Can lung cancer risk among nickel refinery workers be explained by occupational exposures other than nickel? Epidemiology. 2005;16:146-54. http://dx.doi. org/10.1097/01.ede.0000152902.48916.d7.

26. Grimsrud TK, Berge SR, Resmann F, Norseth T, Andersen A. Assessment of historical exposures in a nickel refinery in Norway. Scand J Work Environ Health. 2000;26:338-45. http://dx.doi.org/10.5271/sjweh.551.

27. Kiilunen M, Utela J, Rantanen T, Norppa H, Tossavainen A, Koponen $\mathrm{M}$ et al. Exposure to soluble nickel in electrolytic nickel refining. Ann Occup Hyg. 1997;41:167-88.

28. Roberts RS, Julian JA, Muir DC, Shannon HS. Cancer mortality associated with the high-temperature oxidation of nickel subsulfide. In: Sunderman FWjr, Aitio A, Berlin A, Bishop C, Buringh E, Davis W et al, editors. Nickel in the human environment. Proceedings of a joint symposium held at IARC, Lyon, France, 8-11 March 1983. Lyon: International Agency for Research on Cancer (IARC), 1984. IARC Sci Publ No: 53. p23-35.

29. Roberts RS, Julian JA, Muir DC, Shannon HS. A study of mortality in workers engaged in the mining, smelting, and refining of nickel. II: Mortality from cancer of the respiratory tract and kidney. Toxicol Ind Health. 1989;5:975-93.

30. Haber LT, Erdreicht L, Diamond GL, Maier AM, Ratney $\mathrm{R}$, Zhao $\mathrm{Q}$ et al. Hazard identification and dose response of inhaled nickel-soluble salts. Regul Toxicol Pharmacol. 2000;31:210-30. http://dx.doi.org/10.1006/rtph.2000.1377

31. Oller AR. Respiratory carcinogenicity assessment of soluble nickel compounds. Environ Health Perspect. 2002;110 Suppl 5:841-4. http://dx.doi.org/10.1289/ehp.02110s5841

32. Ontario Department of Health, Environmental Health Services 
Branch. Morbidity and mortality in selected occupations at the International Nickel Company of Canada, Limited; Copper Cliff, Ontario; 1950-1967. Toronto: Ontario Department of Health, 1971. p124.

33. Warner JS. Occupational exposure to airborne nickel in producing and using primary nickel products. In: Sunderman FW, Jr., Aitio A, Berlin A, Bishop C, Buringh E, Davis W et al, editors. Nickel in the human environment. Proceedings of a joint symposium held at IARC, Lyon, France, 8-11 March 1983. Lyon: International Agency for Research on Cancer (IARC), 1984. IARC scientific publications no 53:419-37.

34. Verma DK, Julian JA, Roberts RS, Muir DC, Jadon N, Shaw DS. Polycyclic aromatic hydrocarbons (PAHs): a possible cause of lung cancer mortality among nickel/copper smelter and refinery workers. Am Ind Hyg Assoc J. 1992;53:317-24. http://dx.doi.org/10.1080/15298669291359717.

35. Inco Staff. Operations and plants of Inco; Chapter VIII; Nickel refining. Canadian Mining Journal. 1946;67:457-62.

36. Peek RL. Refining nickel-copper matte at Port Colborne. Engineering and Mining Journal. 1930;130:482-8.

37. Archibald FR. The Kristiansand nickel refinery. J Met [New York]. 1962;14:648-52.

38. Gmelin L. Nickel, Teil A I, System-Nummer 57 [Nickel, Part A I, System number 57]. In: Gmelins Handbuch der anorganischen Chemie [Gmelin's handbook of inorganic chemistry]. Weinheim: Verlag Chemie; 1967. p427-641.

39. Walter HW. Nickel, its history, refining, and uses. Canadian Chemistry. 1931;15:185-94.

40. Gmelin L. Kupfer, Teil A, System-Nummer 60 [Copper, Part A, System number 60]. In: Gmelins Handbuch der anorganischen Chemie [Gmelin's handbook of inorganic chemistry]. Weinheim: Verlag Chemie; 1955. p 2-1465.

41. Newton J, Wilson CL. Electrolytic Refining. In: Metallurgy of Copper. New York: John Wiley \& Sons, Inc.; 1942. p. 250-302.

42. Benard F. Electrolytic Copper Refinery of Ontario Refining Company, Limited, at Copper Cliff, Ontario. Trans Am Inst Min Met Eng. 1933;106:369-97.
43. Roberts RS, Julian JA, Jadon N, Muir DCF. Cancer mortality in Ontario nickel workers: 1950-1984. In: Nieboer E, Nriagu JO, editors. Nickel and human health, current perspectives. New York: John Wiley \& Sons; 1992. p. 629-48.

44. US National Institute of Occupational Safety and Health (NIOSH). Criteria for a recommended standard: Occupational exposure to inorganic nickel. Washington DC: US Government Printing Office, 1977. NIOSH Criteria Documents DHHS (NIOSH) Publication No.: 77-164. 282 p. Available from: http://www.cdc.gov/niosh/77-164.html.

45. US Environmental Protection Agency (EPA). Health Assessment Document for Nickel and Nickel Compounds. Final Report. Washington DC: U.S. EPA, Office of Health and Environmental Assessment, 1986. 472 p. Report No.: EPA/600/8-83/012FF. Available from: http://nepis.epa.gov/ Exe/ZyPURL.cgi?Dockey=30001ACC.txt.

46. Hayes RB. The carcinogenicity of metals in humans Cancer Causes Control. 1997;8:371-85. http://dx.doi. org/10.1023/A:1018457305212.

47. Dr. Ernest Mastromatteo on NIOSH recommendations: Inco's vast experience assists in developing nickel criteria document [Interview]. The (INCO) Triangle. 1977 Jul;37(7):3-5. [Printed by Ontario Division of Inco Metals Company, Copper Cliff, Ontario]. [Available from: http://www.sudburymuseums.ca/ triangle/data/INCOTriangle-19770701.pdf.]

48. Roberts RS, Julian JA, Sweezey D, Muir DC, Shannon HS, Mastromatteo E. A study of mortality in workers engaged in the mining, smelting, and refining of nickel. I: Methodology and mortality by major cause groups. Toxicol Ind Health. 1989;5:957-74.

49. Chovil A, Sutherland RB, Halliday M. Respiratory cancer in a cohort of nickel sinter plant workers. Br J Ind Med. 1981;38:327-33.

50. Enterline PE, Marsh GM. Mortality among workers in a nickel refinery and alloy manufacturing plant in West Virginia. J Natl Cancer Inst. 1982;68:925-33.

Received for publication: 15 August 2011 